\title{
PECULIARITIES OF COMMUNICATIVE APPROACH IN FOREIGN LANGUAGE TEACHING
}

\author{
(CWahedi N., ORCID: 0000-0002-3553-290X, Uzbekistan State University of World Languages, \\ Tashkent, Uzbekistan,nargizawahedi@gmail.com

\section{ОСОБЕННОСТИ КОММУНИКАТИВНОГО ПОДХОДА ПРИ ОБУЧЕНИИ ИНОСТРАННОМУ ЯЗЫКУ}

\author{
СВахеди Н. Г., ORCID: 0000-0002-3553-290Х, Узбекский государственный университет \\ мировых языков, г. Ташкент, Узбекистан,nargizawahedi@gmail.com
}

Abstract. This paper looks briefly at the preconditions that gradually formed communicative language teaching (CLT) as a response to the growing demand and needs of non-native learners of English in many different contexts of learning, then draws a parallel between existing conventional methods of language teaching and novel insights presented by CLT. The constituent parts of Communicative competence are introduced. The negotiation of meaning is considered as the most essential function of the target language that learners are capable to master which allows them to maintain flexibility in a deliberate speech despite the gaps in their language proficiency. Besides, the article discusses the current limitations of CLT bound to several factors such as the lack of language proficiency, rigid curricula, and teachers' misconceptions of CLT.

Аннотащия. В этой статье кратко рассматриваются предпосылки, которые постепенно сформировали коммуникативное обучение языку (CLT) как ответ на растущий спрос и потребности учащихся, изучающих английский язык во многих различных контекстах обучения, также проводится параллель между существующими традиционными методами преподавания и новыми идеями основанными на коммуникативном подходе к изучению языка. Представлены составные части коммуникативной компетенции. Коммуникативная компетенция и умение донести смысловую составляющую считается наиболее важной функцией изучения иностранного языка, которую ученики способны освоить, что позволяет им свободно выражать свои мысли, несмотря на некоторые пробелы во владении языком. Кроме того, в статье обсуждаются текущие ограничения коммуникативного подхода, связанные с несколькими факторами, такими как недостаточный уровень знания языка, жесткие учебные планы и заблуждения касающиеся самой природы коммуникативного подхода в представлениях учителей.

Keywords: communicative approach, communicative competence, communicative language teaching.

Ключевые слова: коммуникативный подход, коммуникативная компетентность, коммуникативное преподавание языка.

The prevalence of non-native speakers of the English language over native speakers has created a huge demand in language teaching methodology. When we observe a long path of language teaching development and witness an abundant number of various paradigm changes in it, it is easy to view that every new approach developed in response to some inevitable limitations and constraints of previous language teaching ideologies. When the Classical method, Grammartranslation method or Audio-lingual method fell out of fashion, in the 1970s, new, innovative approach that has come to be known as Communicative language teaching (CLT) or Communicative Approach appeared. 
Most often, we view language teaching and learning as summative knowledge about analysis of grammar structures, sentence formation, translation of textual information, and comprehension of written material. It is a long-standing tradition to include language learning as a compulsory fundamental part of secondary and high education. Within such academic surroundings, in general, students are capable to read, comprehend complicated texts related to their specific fields, translate them into their native language; they possess a stronghold of grammatical input at all levels of language, such as phonology, morphology, and syntax. As for the language, output students could produce carefully structured accurate strings of sentences, translate texts from L1 (native language) into the target language, discuss a limited range of academic topics strictly related to their domains and within which they have a certain amount of practice. Previous foreign language methods have been limited to these features united around a single general notion of grammatical competence. English teachers conducted classes using teacher-centered, Presentation-Practice-Production mode. In the Presentation stage, the teacher introduced a new grammatical structure based on supplementary material such as a short text or a dialogue illustrating covered grammar rule. A brief comprehension check of the explained material followed. In the Practice stage, students did drilling exercises to imitate the newly learned structure. In the last stage, Production, students were encouraged to produce independent chunks attempting to use the pattern without any supplementary material.

A neglected area in the field of grammatical competence was fluency development and pragmatic competence. It was proved the case that when learners found themselves in normal, reallife situational context, they failed to produce meaningful output appropriate to spontaneous situations. This phenomenon has been widely observed in parts of the world where English had a status as EFL (English as a Foreign Language) and not as ESL (English as a Second Language), and learned in an artificial surrounding, which means that the only place for learners to practice the newly acquired language elements was their classroom within assigned lesson time. Consequently, lack or absence of exposure to authentic language environment inside and in some locations outside a class called into question the validity of previous methodologies and created preconditions for CLT.

Globalization around the world resulting in extensive immigration flows turned the direction in English language teaching from academically related analytical knowledge about a language to more practically oriented everyday communication in it. In particular, increase in immigration in such locations as USA, The Great Britain, in some parts of Europe urged English teachers, scholars, textbook writers, policy developers recognize the augmenting need to shift attention away from grammatical competence and sophisticated analysis of language to more practical use of the target language in the contemporary society [1, p. 263]. The primary concern of all non-native speakers of English was to learn how to communicate in a foreign language effectively; to understand and decode the received information and to transfer the message through verbal channel meaningfully ensuring that the interlocutor comprehends fully and in turn, provides a response. In other words, CLT has been developed as a response to a growing need of learners who wanted to be able to use a target language in various social contexts. Thus, knowing the rules employed in sentence formation and constructing accurate sentences on a paper did not prove helpful when there appeared a need to be engaged in meaningful communication. This approach prioritized gaining an insight in language functions. Communicative competence, the term with interdisciplinary status, first used in sociolinguistics became a central tenet of CLT. The communicative competence is the ability of language learners to differentiate social situations following their status, level of formality and use with pragmatic skillfulness chunks of language that are appropriate to the chosen context. The aim is to create an immersive teaching environment where learners through guided input and constant 
practice acquire both native-like accuracy and fluency and can adjust their output in different social settings and attain a communicative intent. The most challenging task for a language learner in CLT is to detect pragmatic nuances in language "which native speakers of language often take for granted" [2, p. 18].

In the 1980s, with further development of CLT, Canadian scholars Canale and Swain based on their observations of French students' language acquisition in line with grammatical competence introduced four additional constituents of communicative competence. [3, p. 5]. First, sociolinguistic competence is the capability of understanding general patterns that govern the society, social norms, implicit subtle nuances in social interaction, speech etiquette, cultural influence on social behavior in which language is used. Second, discourse competence is a recognition of different text types; a thorough comprehension of larger units of language, the proficiency to analyze and to decode implicit socio-cultural information within the inner part of a discourse that is only accessible to native speakers of a certain socio-cultural community. Also, discourse competence is the differentiation of coherence and cohesion that provides unity for a text. Coherence introduces logical connection of ideas presented within deeper implicit layers of a text while cohesion serves to link sentences structurally through cohesive devices essentially bridging words, pronouns, and synonyms.

Third, strategic competence represents the ability of a learner to use different communicative strategies to maintain the conversation despite their limitations in the target language; the strategies that assist learners to fulfill their communicative needs, for example, elaborative probing comprehension questions for ensuring successful message transmission, conversation fillers, paraphrases or skillful use of synonyms. Lastly, grammatical competence is the correct and appropriate usage of grammatical patterns in building meaningful communication units. According to S. Savignon, communicative competence progressive and powerful interpersonal phenomenon as it shaped in the communicative process of people who belong to the same linguistic community [Savignon, 270]. Within the scope of communicative competence, the notion of negotiation of meanings has come to be used to refer to the necessity of constant communicative practice during the entire process of foreign language acquisition for developing communicative abilities. Thus, ensuring further enhancement and productivity in foreign language teaching programs and procedures, "grammar-based methodologies such as the P-P-P have given way to functional and skills-based teaching, and accuracy activities such as drill and grammar practice have been replaced by fluency activities based on interactive small-group work'[4, p. 8].

It is possible to summarize the core principles of CLT as follows:

A learner with communicative competence understands that language is a complex phenomenon with several aims and possesses all necessary skills to transfer a verbal message successfully;

A learner can produce different output following the framework and participants; he comprehends the necessity to react appropriately to different contexts such as formal or informal, oral or written, higher versus lower status;

A learner is proficient in differentiating types of texts, knows their peculiar features and can reproduce them, for example, narratives, reports, interviews; he skillfully employs communication strategies for maintaining message transmission [4, p. 3].

CLT has formulated a fundamentally different view of a lesson format as well as the roles of teachers and learners in it. Earlier perceptions of foreign language learning methodology generally relied on behaviorism ideology that suggested mechanical habit formation through constant drilling patterns and teacher controlled output as the primary way to achieve mastery of a target language. In CLT, the entire format of a lesson has undergone a considerable change. Cooperation and 
interaction among learners became central constituents for conducting a class. CLT shifts attention from a traditional teacher-centered model to a learner-centered approach where students do not view a teacher as a model to imitate; instead, they attempt to create meaningful communicative units by experimenting to express themselves in different contextual situations. Teachers perform roles of facilitators, providing constructive feedback on their performance. Negotiation of meaning is of the utmost importance "as the learner and his or her interlocutor arrive at understanding", [4, p. 4]. Previous activities that used to imply strong teacher-controlled learner output that inevitably led to avoidance of errors were substituted by pair, group and teamwork activities that reinforce learners' cooperation, foster mutual communication among learners and create a positive non-judgmental atmosphere for prolonged learner responses.

Although CLT paradigm has revolutionized the existing teaching context and has gained wide popularity among scholars, to the present day, there are some challenges revealed that need further contemplation. The main limitation of CLT, which is often criticized for, is its inefficiency in applying in locations where the English language is studied as EFL, (where learners' opportunities to utilize a target language constrained by absence of English speaking participants away from the class), and not as ESL (where learners can re-explore learned material in natural English speaking environment). Impossibility to practice a target language outside the classroom hinders learners' progress in language acquisition. Thus, many critics conclude that CLT practices are not pertinent enough to be used in EFL context.

Another problem in the applicability of CLT stems from institutional requirements and reasons. It is known that the majority of educational institutions have their own set of policies along with a rigid curriculum to govern language education with preset learning outcomes. As CLT is a content-dependent approach, it should be related to learners' needs finding its reflection in the course curriculum. Ideally, we should tailor specific solutions to specific problems. However, overall, learners' language progression evaluated regularly and academic performance has paramount importance in terms of learners' future high education prospects. Apparently, in this type of institutions teachers place much more emphasis on curriculum content and prioritize to cover materials present in the language-focused curriculum to ensure students pass grammar-based examinations.

Furthermore, several studies suggested that many EFL and ESL teachers claimed that they conduct classes under CLT approach. It is rather paradoxical however, that their detailed accounts on their teaching do not correspond to core principles of CLT [5, 6]. Lack of confidence, personal beliefs, and misconceptions about the communicative approach, no expertise in developing appropriate CLT materials are the limitations that EFL instructors claim to experience most often. On the one hand, concerning teacher performance in the class, it has been argued that many teachers are not proficient enough in strategic and socio-cultural competence; besides, deficiency in oral skills pose a huge challenge to base all class activities around speaking skills. On the other hand, as reported by Deckert, excessive teacher talk is another major hindrance that constantly violates the principles of CLT. In her observation of ESL classes, she found that overall "instructors were speaking anywhere from two to five times more often than all their students combined" [6, p. 14]. Even so, speaking is an important dimension of language learning, we still regard this skill as the most anxiety-causing stressful experience.

Likewise, the absence of teacher training courses where teachers could deepen their theoretical knowledge about the communicative approach, master teaching strategies, enrich their experience adds to the problematic issues of CLT.

In summary, without regard to some constraints for CLT development in a foreign languageteaching context, it has the potential to involve both EFL teachers and learners in shaping 
personally oriented content that in turn, allows creating many opportunities for meaningful language use. Individual language development is encouraged through the negotiation of meaning and the engagement in communicative activities. Besides, EFL teachers opt for professional growth while they re-design the entire class materials to relate them to learners' communicative experiences.

\section{References:}

1. Savignon, S. J. (1991). Communicative Language Teaching: State of the Art. TESOL Quarterly, 25, (2), 261-277.

2. Duff, P. (2014). Communicative Language Teaching. Teaching English as a Second or Foreign Language. Boston: USA, 15-31

3. Canale, M., \& Swain, M. (1980). Theoretical bases of communicative approaches to second language teaching and testing. Applied Linguistics 1 (1), 1-47.

4. Richards, J. C. (2006). Communicative Language Teaching Today. Cambridge: Cambridge University Press, 52.

5. Li, D. (1998). It's always more difficult than you plan and imagine: Teachers' perceived difficulties in introducing the communicative approach in South Korea. TESOL Quarterly, 32(2), 677.

6. Deckert, G. (2004) The Communicative Approach: Addressing Frequent Failure. English Teaching Forum, 42(1). 12-17.

\section{Список литературы:}

1. Savignon S. J. Communicative Language Teaching: State of the Art // TESOL Quarterly, 1991. V. 25, No.2. P. 261-277.

2. Duff P. Communicative Language Teaching. Teaching English as a Second or Foreign Language. Boston: USA, 2014. P. 15-31.

3. Canale M., Swain M. Theoretical bases of communicative approaches to second language teaching and testing. Applied Linguistics. 1980. 1(1). P. 1-47.

4. Richards J. C. Communicative Language Teaching Today. Cambridge: Cambridge University Press, 2006. 52.

5. Li D. It's always more difficult than you plan and imagine: Teachers' perceived difficulties in introducing the communicative approach in South Korea// TESOL Quarterly, 1998. 32(2). P. 677703.

6. Deckert G. The Communicative Approach: Addressing Frequent Failure // English Teaching Forum. 2004. V. 42. Is. 1. P. 12-17.

Работа поступила

в редакичию 14.01.2020 2.
Принята к публикациии 19.01.2020 2.

Ссылка для циттирования:

Wahedi N. Peculiarities of Communicative Approach in Foreign Language Teaching // Бюллетень науки и практики. 2020. Т. 6. №2. С. 297-301. https://doi.org/10.33619/2414$2948 / 51 / 35$

Cite as (APA):

Wahedi, N. (2020). Peculiarities of Communicative Approach in Foreign Language Teaching. Bulletin of Science and Practice, 6(2), 293-301. https://doi.org/10.33619/2414-2948/51/35 